\title{
The Glenmasan Manuscript
}

\section{Author(s): Professor Mackinnon}

Source: The Celtic Review, Vol. 3, No. 11 (Jan. 15, 1907), pp. 198-215

Stable URL: http://www.jstor.org/stable/30023305

Accessed: 27-06-2016 02:58 UTC

Your use of the JSTOR archive indicates your acceptance of the Terms \& Conditions of Use, available at

http://about.jstor.org/terms

JSTOR is a not-for-profit service that helps scholars, researchers, and students discover, use, and build upon a wide range of content in a trusted digital archive. We use information technology and tools to increase productivity and facilitate new forms of scholarship. For more information about JSTOR, please contact support@jstor.org. 


\title{
THE GLENMASAN MANUSCRIPT
}

\author{
Professor Mackinnon
}

\section{GAELIC TEXT}

Dala b-fer n-Erenn. O rangatar Dun Fliduisi ro gabadh sosad agus longport aca ann. Is ann sin do deónaigetar cetri trein-fhir thogaidhe trom-gnimach do muinntir morcalma Meadba dol do denam echt agus aitius ar in Gamanraid. Agus ba h-iat a n-anmanda, .i. Carra mac Charra Chongna agus Mongach Milidh agus Letriach Laimdherg agus Cuillend curad ${ }^{1}$ garb. Agus fa h-iat so na treín-fhir ro togsat do chómrac cuca, .i. Carra mac Carra Congna do dol go Dun Coirrsleibhi go h-Aed mac Echtaig, agus Mongach Milidh co Dún Letriach, co h-airm ar raibe Muredach mend mac Oilella Finn, agus Cuillend coscrach go Dún Flainn mic Fidaigh go Leitir, agus ${ }^{2}$ Letriach Láimderg co Dún-os-Loch co Muincend Milidh.

Cid tra acht bá h-e cet fer innister gnimartha ann so, .i. Carra mac Carra Congna. Ranic sein go dunad Aedha mic Echtaigh, agus tarla Aed mac Echtaig dó. Agus ro gab sein (ag) acallaim in fir moir, agus adubairt an laidh ann :-

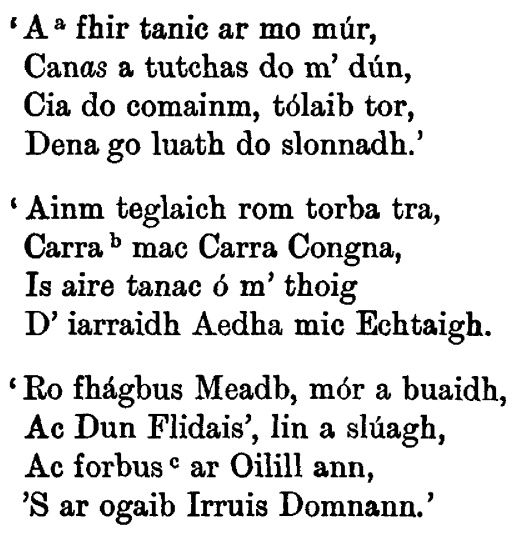

' $\mathrm{A}$ a fhir tanic ar mo múr, Canas a tutchas do m' dún, Cia do comainm, tólaib tor, Dena go luath do slonnadh.'

'Ainm teglaich rom torba tra, Carra $^{b}$ mac Carra Congna, Is aire tanac ó $\mathrm{m}^{\prime}$ thoig D' iarraidh Aedha mic Echtaigh.

'Ro fhágbus Meadb, mór a buaidh, Ac Dun Flidais', lin a slúagh, Ac forbus ${ }^{c}$ ar Oilill ann, 'S ar ogaib Irruis Domnann.'

\footnotetext{
2 Here begins the parallel version in Y.B.L., p. 331. The more important variants are noted.

b Corrad.

${ }^{c}$ forbaisi.
} 
(Continued from pp. 136, 137.)

\section{ENGLISH TRANSLATION}

As to the men of Ireland. When they arrived at Flidais's Dun they halted and pitched their camp there. It was then that four select mighty men of prowess of Meave's very brave people set forth to win renown and fame among the Gamhanraidh. These were their names,-Carra son of Carra Congna, and Mongach the warrior, and Letriach Red-hand, and Cuillend stalwart champion. And these were the warriors whom they selected to fight against, viz., Carra son of Carra Congna against Aodh son of Echtach in Dun Round-hill, and Mongach the soldier against Muiredach the stammerer, son of Oilill the Fair, in Dun Letriach, and the victorious Cuillend against Flann son of Fidach in his Dun in Letter, and Letriach Red-hand against Muincend the warrior in Dun-above-Loch.

Now the proceedings of Carra son of Carra Congna are the first recorded here. He went to Aodh son of Echtach's castle, and Aodh son of Echtach met him. And he (Aodh) began to address the stout man and recited the lay :-

- Thou who hast come to my walls, Say what has brought thee to my Dun, What is thy name, so please you? Declare at once who you are.'

'My family name, I take pride in it(?), Is Carra son of Carra Congna ;

What has brought me from my home, Is to seek Aodh son of Echtach.

'I have left Meave, great her renown, At Dun Flidais, numerous her host, Challenging Oilill there, And the warriors of Irrus Domnann.' 
'Mairg tanic o tinol mór, 'S do sgar ré socraide sloig; An toisg tuc tú ó d' thig, Is let bus aithrech, a fhir.'

A fhir.

Ahaitli na laide sin ro comraicset in $\mathrm{da}^{1}$ churaidh sin. Agus do ronsat comrac a crodha ${ }^{b}$ curata cumfhuacdha aindfercach ainíarda, gor brisiter a sceith agus gor cám-lubtar a cloidme is in comlainn. Acht ata ní $\mathrm{c}(\mathrm{h})$ ena $^{\mathrm{b}}$ : ro fortamlaigh Oedh mac Echtaigh an t-airsid ar Carra mac Carra Congna gor ben a cenn de is in comlainn ar sin.

Do chuaidh Mongach ${ }^{\mathfrak{c}}$ do cuingid comraic ar Muiredach menn mac Oilella Finn, agus do raidh Muiredach nach erfad am comrac ${ }^{\mathrm{d}}$ an deg fer, agus do ronsat an laeidh iar tain :-

Column 68.

'A $\mathrm{f}(\mathrm{h}) \mathrm{ir}^{\mathrm{e}}$ moir is mo d' feruibh, Ni d' érf $a$ tu im debaid;

Cid ad seghainn, slicht amne, Ni-d-fia $\operatorname{cor}^{f}$ na comairci ?'

' Da n-dernta mo t(h)oisg a stoigh, Ro-d-fia maitheam anacail, A radh re Muiredach menn Comrac re ${ }^{2}$ Mongach Mailcenn.'

'Is misi Muiredach mor, Lem an dun-sa con a $\operatorname{slogh}^{3}$; Maithem ort ni sirfi sinn, $\mathrm{Ni}$ targa aein fer etraind.

'A Mongaig(h) is mor do grain, Ni ma tangais i m' dáil, Do bhadha bhid badh ${ }^{8}$ fir baeith A derim rit is fir.' $h$

$$
\text { A fhir. }
$$

Do ronsat iar sin comlonn fergach fortamail fedhmannda, agus urrlin $^{i}$ ogla fhaebar-cruaidh ainiarmartach, agus debaid dichra di-fregra do-eistechta, gur ba lír fuil agus feoil tesga ar
a comlonn.
d im debaid.
b:b Y.B.L. omits.
e laich.
g bagha bid baidh.
b a laich.
c Moach.
e cuir.
i urrlaidi. 


\section{THE GLENMASAN MANUSCRIPT}

'Pity to have come from the great muster, And to have parted from the huge hosts ;

The quest that brought thee here,

Thou shalt rue it, $\mathbf{O}$ warrior.'

Thou.

After reciting this lay the warriors fought. And they made a brave heroic stern wrathful angry fight. They broke their shields and bent their swords in the conflict. In the event the veteran Aodh son of Echtach mastered Carra son of Carra Congna and cut off his head in that duel.

Mongach went to challenge Muiredach the stammerer, son of Oilill the Fair, to combat. Muiredach said that he would on no account decline to fight the stout warrior, and they made the lay thereafter :-

'Thou biggest of big men,

I shall not decline your challenge:

Why should I avoid you, as matters are,

The fixing of conditions does not lie with you?'

'Should you carry my message to the castle,

You will have assurance of protection,

Seek from Muiredach the stammerer,

A duel with Mongach Bald-head.'

'I am the great Muiredach;

Mine this fortress and its hosts ;

I assure you we shall not be sought after,

No one will offer to separate us.

'Mongach, great is your arrogance,

In seeking a meeting with me,

Your boasts are those of a vain man,

I tell you of a truth.'

O man.

They then fought an angry valorous and well-sustained duel, and a fearful indecisive contest with steel blades, and a fierce reckless unheard-of quarrel, until the combatants were one mass of gore and hacked flesh. Eventually Mongach

\footnotetext{
1 MS. in da na. $\quad 2$ In MS. re is written on the top margin. ${ }^{3}$ MS. sluagh.
} 
na feraib, go torchair Mongach le Muiredach is in móirgliaidh, agus do ben a a cenn d' á cholainn.

Do chuaid Letriach, laech-milidh do muinntir Medba, ar amus Muincinn milidh,.i. búachaill na Maili Flidaisi. Agus is ed ba menmarc do Letriach co m-berad an Maol Fhlidhaise con a búachaill leis; úair do commaidh re muinntir go $\mathrm{m}$-beradh leis $\mathrm{h}$-í. Agus tanic a timchell na h-alma ${ }^{b}$ co h-ainhíardha. Agus eirgis Muinceinn do'n milidh, agus ro aguill $e$, agus abert an laeid :-

\footnotetext{
- A fhir do ní an reim curad, Mor do laechaib do rubadh; Mh' ealua fuil is in choill, $\mathrm{Ni}$ bera let gan comroinn.'

A áthaig fuil ag na buaib, Uathad ${ }^{c}$ duit in diaigh in buair ; In b-fuil agad, tolaib tor, Do muinntir acht tu a t' aenar?'

-Atú-sa sunn, slicht imne, Ag ingaire na Maile; Nocha n-fuil laech, lith gan choll, Ro-s-bera uaim gan comlond.'

" "Ni troitfinn rit fa t' alma," Orsat milidh mor calma, "Da n-imthighe ród do d' thig 'S da fagtha d $(t) h$ ' alma, a fhir."
}

A fhir.

Adubairt Letriach re Muincenn an Máel Fhlidaisi do dilsiugadh agus co tibrad fein maithem n-anacail dó. Nír bó miad lé Múincend an ni sin, .i. aon laoch is in doman do breith a ealua agus a innile uadha d' a ainndeoin. Agus do cuatar achetoir a crislaigthibh a sgiath, agus a $\mathrm{m}^{1}$-bolgánaib ${ }^{\mathrm{f}}$ a sleg rinn-gér ro fhada, agus a n-urrdornaib a cloideam cruaidh-ger clais-lethan. Agus do rónsat in dá cathmílidh sin comlond calma curata, gur cám-lubtar a cloidme is na clar-sgiathaib, agus do sníetar ${ }^{2}$ na slegha ris na sír ${ }^{\mathrm{g}}$-sháitaib, agus do

a go tobacht Muiredach.

b h-albha. This word is almost invariably written in Y.B.L. with $b$ instead of $m$.

c t'aenur. d faca. 't'alba. f bolgsenaib. B sith. 
fell in the fierce onset, and Muiredach cut his head off his body.

Letriach, a valorous soldier of Meave's army, went forth to meet the warrior Muincenn (Hairy-head) who was the herd of the Maol Flidais. Letriach's great desire was to carry away the Maol Flidais and her herdsman; for he boasted among his people that he would do so. He viewed the cattle in angry mood. Muincenn met the warrior, and had speech with him, when this lay was recited :-

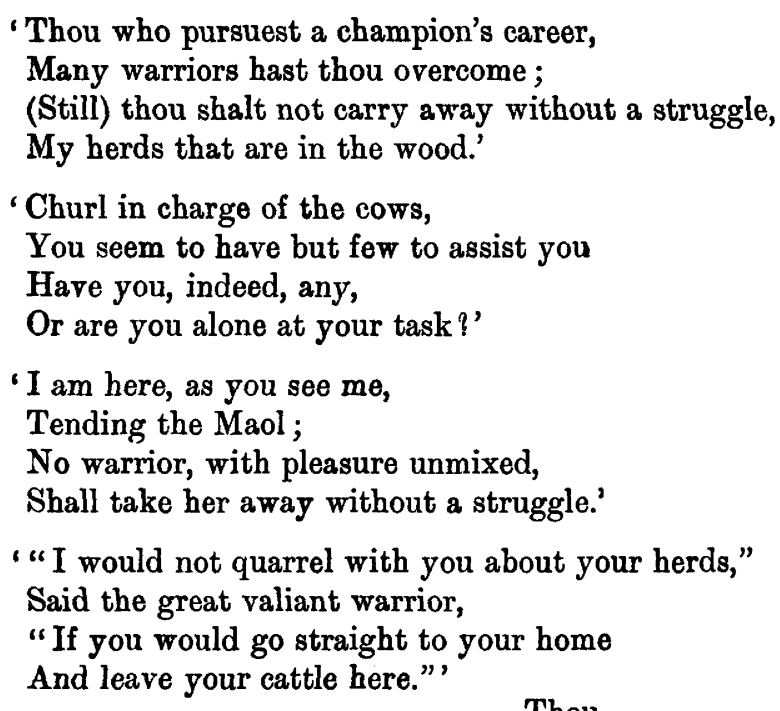

Thou.

Letriach told Muincenn to surrender the Maol Flidais, and that he would give him quarter. But Muincenn was too proud to allow any champion in the world to carry away his herds and cattle by force. The warriors forthwith buckled on their shields, and grasped their long sharp-pointed spears in the centre, and their steel-hard broad-grooved swords by the hilts. And the two battle-soldiers fought a sturdy valorous duel ; and their swords were bent against the wooden shields,

1 The Y.B.L. variant bolgsenaib shows the word to be that now written buillsgean, meaning 'the centre of.' Cf. for S.G. Ps. xlvi. 2 (metr.); Ossian (ed. 1818, p. 7); John Morrison, i. p. 165.

2 I take the word to be the modern snaidheadh, 'hacking,' "whittling'; in S.G. specially applied to cutting and carving of stones and wood. 
cromatar a cinn ris na colg-beimennaib, agus gur corcrait a Column 69. cinn do na cath-fersdib, ${ }^{1}$ agus gur tesgait a táib trés na tromlúirechaib, gur dibad an airm fá na h-anradaib as a h-aithle. Agus do siniter ${ }^{b}$ a lamha tar laech-formnaibh a chele. Agus tucatar treas ${ }^{c}$ confaid agus coingleca, mell-gaile agus mullacraide, ${ }^{2}$ gur cuiretar snadmanna curad ar na corpaib, gur sínetar a $\mathrm{n}$-asnadha agus a $\mathrm{n}$-airbech, ${ }^{3}$ gur lubatar a tosaige go troigthib ${ }^{4}$, agus gur geinetar srotha doirbe der-troma dluthallais a h-aightib na n-anrad, agus a formnaib na fer-oclach, agus a taobaib na trein-miled do'n treas sin. Cid tra acht ro tráethad agus ro trascrad agus ro troim-legad Muincinn do'n mell-gail sin. Ro cúradh ${ }^{5}$ agus ro cengladh agus ro cuibhrigedh in curaidh do'n caingin sin. Agus ro tógaibh Letriach ar a formnad é as a h-ait(h)li. Agus ro gab ic áisc agus ag acullaim fair, ag fochuidmead agus ag fanamhad faei. Agus adubairt go m-bérad a fiadhnaise Medba an milidh. Agus ro raid-sium co n-dingned re h-aimsir ' $\mathrm{n}$ a fecmuis. 'Nocha ${ }^{\mathrm{e}}$ i d' lain-ched legfiter,' uar Letriach. Agus adrubatar an laeid ann :-

\footnotetext{
'Tarr, a Muincinn, suas

Go luath air mo muin;

Da m-berar tu soir

Beidídh broin fa t' fhuil.'

' Conair beri mi,

A Letriach go lúas?

Ro budh ferr lim tís,

Gid oibhni dam túas.'

- Do cifif tu Meadb

Is Oilill an ri ;

Cus a n-iug re m' ré,

Ita ' $\mathrm{me}$ ar do thi.' ${ }^{6}$
}

a Y.B.L. adds gur brisit an lanna do na laec-bhemendhaibh. b désedar.

c Y.B.L. adds crisgaili agus. a ais.

f chithfea.

g Ataime. Y.B.L. p. 332.

1 Now fearsaid, and meaning 'spindle' both in S.G. and I.G. In topography, the word is applied to 'a sandbank formed near the mouth of a river,' whence Joyce (i. 348) derives Belfast (Bel-feirsde). So in Lochaber (Beauties of Gaelic Poetry, p. 17):' 'S ann a bha cuid de m' shinnsribh Eadar an Innse 's an Fhearsaid.'

2 mullacrad. The word is obscure to me. A collective from mullach? 
and their spear-(shafts) whittled by the perpetual thrusts, and their heads were bowed by the sword blows, and wounded by the battle maces, and their sides were cut through the heavy coats of mail, until finally their weapons were rendered useless. Then they stretched their hands across each other's mighty shoulders. And they had a wrestling bout, furious, sustained, and strong, so that they twisted each other's stout bodies, and strained ribs and sides, and pulled each other's heads to the ground. Rough streams in big drops of thick sweat poured from the faces of the champions, and from the shoulders of the brave warriors, and from the sides of the mighty soldiers in that struggle. At length Muincenn was overcome and prostrated and heavily thrown in that stout encounter. The hero was bound and tied and fettered in the issue of the contest. Letriach raised him on his shoulders thereafter. He spoke to him in upbraiding scornful derisive language. He said that he would bring the warrior into the presence of Meave. Muincenn replied that for a season he could do well without that honour. 'Your leave will not be asked in the matter,' said Letriach. And they recited this lay then :-

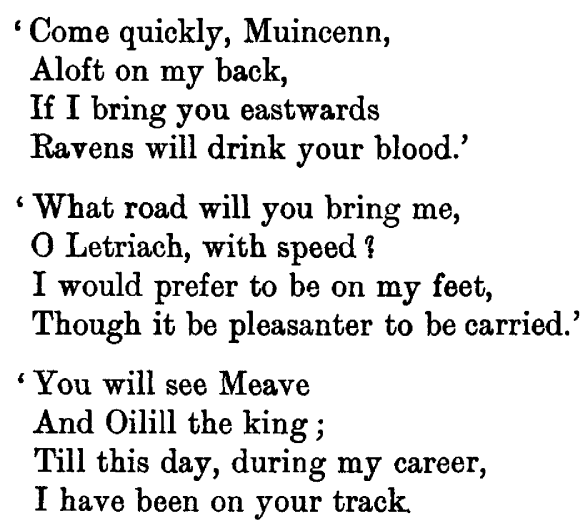

\footnotetext{
3 airbech : evidently a by-form of airbe, 'ribs,' 'fence,' 'phalanx' (K. M.).

4 Alliteration no doubt caused the use of tosach, now toiseach, in this phrase for ceann. Why not, however, gur lubatar a cinn gu cosaib?

- Still in use but rather in the sense of mental distress, 'torture.'

6 Nowadays one would write air do thoir ; but for this use of $t \ddot{\imath}$ cf. vol. i., p. 118,
} n. 5. 


\footnotetext{
'Berud-sa tu lem

Go beraib noi rend;

Dergfuider do cru $;^{1}$

Teilefeat tu 'na cend.

'Ac sin duid do dil;

Ole do t' din do sbairn;

Fann a nocht do treoir,

Beid eoin ar do tárr.'
}

Tarr a Muincinn.

A h-aitli na laeide-sin ro gluais Leitriach go lan-dedla do lathair, agus Muincinn milidh ar a mhuin.

Agus tuc Muincinn d' a uidh agus d' a aire ar sin nach raibhe lucht a cumairci d' á cairdibh 'n a comfocus, ná lin a f hostoid d' a urradhuib in a fiadhnaise. Agus do tuic fos go firinnech go fuighbedh fein go tenn a traethad, madh do roiched le. Leitriach a luath-imchar. Agus nir cian ranic Leitriach do'n lathair sin an uair a tuc Muinchenn milidh column 70. clisiud sprancdha sbindamail ${ }^{2}$ go calma curata d'a ballaib ${ }^{b}$ uadha is na cenglaib agus is na cruadh-cuibhrigib bui fair, ${ }^{c}$ go raibi luamairecht a lam agus cothugadh a chos ar comus do'n curaidh. Agus ar rochtain na talman co tenn d' a troigthib, ro iadastar a da doít-righ degh-lamaig a muidh tar rigthib an rígh-miled go ro calma, co $n$-ár leig impodh ${ }^{d}$ na cothugadh $^{\text {e }}$ na caraighecht na clesamnacht do'n curaidh, acht ro chuir a glun a filliud ${ }^{3}$ a coisi, agus ro leg tar a ais síar an saer-milidh co raibi faén fo tharrsna fáei. Agus ro cocraidh $g$ agus ro cengail co calma an cath-milidh, agus adubairt iar sin co tibrad cumaéin a imchuir do'n áirsigh. Do fiarfaig Letriach gá conair gus a n-ímarcuirfed h-é. 'Nocha d' fis Oilella na Meadbha imarcuirfet-sa thú,' ar Muincenn, 'acht síar co

a $\tan$.

b cruaidhengaibh.

c Y.B.L. adds gor bris na téda go tindesnach, agus gor bruidh na h-ialla co h-arrachta, go nach roibe fedhm ar eill na ar téd na ar tren-lomain dar choraidh in milidh ar Muinceann (and quickly broke the cords, and strongly burst the thongs, so that the thongs and cords and stout ropes with which the warrior bound Muincenn were of no avail). d fossud. e fathugud. $\quad f$ fortrasna. $\quad \mathrm{g}$ crapaill.

1 Is cru for cró, 'pen,' etc., metaphorically applied to Muincenn's bed of torture ? cró is masc., and one would expect chend in the next line. It would be a bold 


\author{
'I shall carry you \\ To the nine-pronged spits ; \\ Your bed will be made red hot, \\ You will be cast into it. \\ ' That will be your lot, \\ Your efforts will be of no avail ; \\ This night your pith is feeble; \\ Birds of prey will peck at your entrails.'
}

Come, Muincenn.

After this lay Letriach moved from the scene of the conflict full speedily, with Muincenn the warrior on his back.

Muincenn was fully alive to the fact that his friends who could protect him were not nigh him, nor a sufficient number of supporters within reach. He felt besides quite convinced that should Letriach manage to carry him away speedily, a violent and certain death awaited him. Letriach did not proceed far when Muincenn the warrior by a sudden vigorous spring freed his limbs bravely and valorously from the cords and hard fetters by which he was bound, so that the champion was able to fling his hands about and struggle with his feet. When his feet caught a firm footing on the ground, he wound his powerful well-trained arms most firmly around the arms of the royal warrior, so that the champion could neither turn nor fight nor wrestle nor struggle. He then planted his knee to intercept the other's foot, and pressed the noble warrior backwards so that he fell under him prone. $\mathrm{He}$ fettered and bound the battle-warrior securely, and said that he would now give a return ride to the veteran. Letriach inquired in what direction he meant to carry him. 'I shall not bring you to Oilill and Meave,' said Muincenn, 'but back

metaphor to say that his blood (cró) or even his raw flesh (crú) would be made red, and the following line would, by such rendering, lose point.

2 clisiud sprancdha sbindamail : a graphic phrase,-clisiud is the verbal noun of clisim, cf. S.G. clis, 'quick'; sprancdha is not in use now, but the first John of Ardnamurchan, from whom that sept of the Macdonalds was called Clann Iain, MacIan's, was known as John Sprangach because of his activity; spionnadh, 'strength,' is common both in I.G. and S.G., but the adj. spionnamhail, retained in I.G., has been disused in S.G.

${ }^{3}$ This feat in wrestling is known in some districts as cas bhacain. 
bordaibh an dub-loich-sa ${ }^{1}$ do $\mathrm{t}^{\prime}$ dían-badudh, indus co $\mathrm{m}-b a d^{\text {a }}$ uait sluinnfider an loch-sa co lán-deimin, uair ni ticfair d' iarraidh buáir ${ }^{b}$ co bráth a rís.' Agus adubratar in láid :-

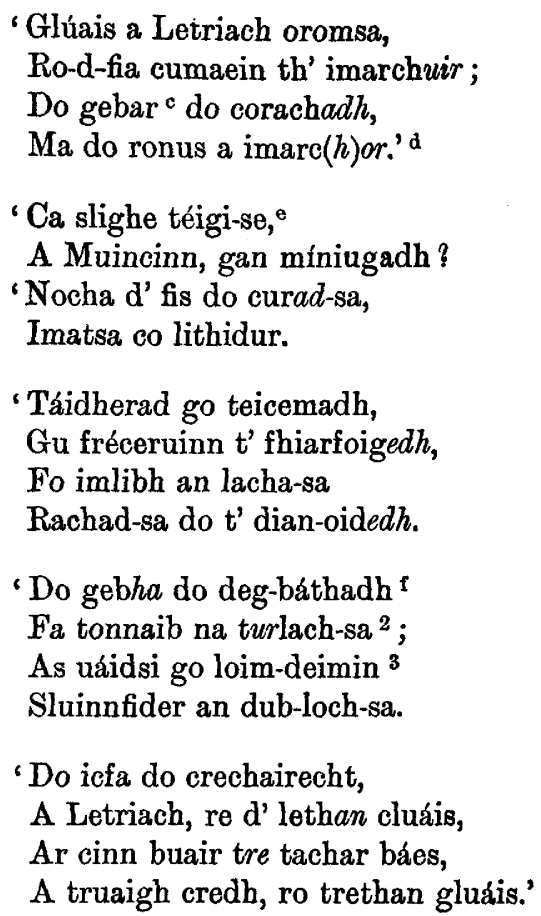

Gluais.

A h-aitli na laeidhe sin togbais Muincinn Letriach go h-ard ar a formna, agus ráinic reime go bord an locha go láin-dian. Agus ro gab Letriach go lan-prap ${ }^{4}$ ind a dí láimh, agus ro dibraich is in loch an rig-milid, gor baithetar dobur-linnti duaibhsecha an dub-locha an deg fer, conad uad ainmnigter an loch re lenmain. Agus ro h-imthigh Muincinn roime iar sin, agus ro coraig a elmha agus a indili go h-urmaisnech.

\footnotetext{
a gomahuait.

b Y.B.L. $\alpha d d s$ ar baesrach.

c gebha da corachaind.

d ceart ronchad $m$ ' imarchair.

f dian-bathadh.

g laech.

I MS. loingus, corrected to loich-sa. 
to the margin of this dark lake, and speedily drown you, and the lake will assuredly be named after you, for you will never again come in search of cattle. And they said the lay :-

'Come, Letriach, on my back,

You will now, in turn, be carried ;

You will receive such treatment

As you have given to me.'

'What road will you take,

Muincenn, answer briefly?'

'Not to the presence of your champions

That they may rejoice at seeing you.

'But, to reply to your inquiry,

We shall quietly go forward

To the borders of this lake,

And to your swift destruction.

'You will be effectually drowned

Under the waves of this winter lake;

From you most assuredly,

The dark loch will be named.

' Your plundering career,

Letriach, will come to a close (?),

In quest of cattle, a mad venture,

Wretched man, speed through the waves.

Move.

After this lay Muincenn raised Letriach aloft on his shoulders, and went to the edge of the lake full swiftly. And in a twinkling he seized Letriach in his two hands and flung the royal warrior into the lake, so that the stout soldier was drowned in the dangerous water-pools of the dark lake, which was afterwards named after him. Muincenn thereafter wended his way to his herds and cattle which he tended right carefully.

2 turlach from tur, 'dry,' and loch, 'lake,' is not in use in S.G. We bave tùrlach, quite a different word, meaning 'a large fire,' as in the couplet :-

'Shéidinn sop is dheanainn tùrlach,

Loisginn A puinn mhic Iain Stiubhart.'

3 Cf. S.G. lom-làn, 'full to the brim.'

4 prap. From prap, 'sudden,' came the I.G. phrase le praib na suil, S.G. am briobadh na sull, 'in the twinkling of the eyes.'

VOL. III. 
Is ann sin rainic reme Cuilenn, cath-milidh do muinntir Medba agus Oilella, d' fuaccar comraig agus comloind ar Flann Column 71. Fhoda mac Fidaigh. Agus ránic reime go dunadh Flainn, agus ro ingantaichsed lucht an dunaidh a indiull agus a écuse agus a forgruamdhacht. Ro fiarfaig an doirrseoir sgela, de i. ca $\mathrm{h}$-inadh gus a $\mathrm{m}$-bui $a$ tosca $^{b}$ agus a turas. Agus ro indesium gurab d' fuagar comraig tánic ar Flann Fada mac Fidaigh. 'Agus erich-si, a doirseoir,' ar se, 'agus indes do Flann aein fer ${ }^{1}$ sunn ${ }^{\mathbf{c}}$ ag iarraidh comraig fair.' 'Ca h-ainm-si ?' ar an doirseoir. 'Cuilenn ${ }^{d} m^{\prime}$ ainm-si,' uar eisium, 'agus as dam ata an dán Flann Fada do marbadh. As aire sin tanuc d' fhuacar comraig agus comloind fair.' Agus do ráid an laeidh ann :-

' A doirrseoir ud dunaid e Flainn,

Nech ${ }^{f}$ sunn ag iarraidh comloinn,

Trein-fer do muinntir Meadbha,

Indeis tall do t' tigerna.'

'A oglaich an gotha gairb, Abair rimsa caidhe(t)h'ainm, Go n-inniser tall a sticch $\mathrm{g}$ Do Flann Fhoda mac Fhidhaigh.

' Misi Cuillenn cruaid mogha, Is mi marbus Flann Fada; Marbuim ced a lo gaili, Nocha ${ }^{\text {h }}$ breg, a doirrsiri.'

A doirrseoir.

Ar sin do erigh Flann Fada ${ }^{i}$ a mach a coinde Cuilinn agus adbert fris ${ }^{i}$ : 'A Cuilinn,' ar sé, 'má ata do nirt nó do níaachas ${ }^{2}$ indad frithoil mo comlann-sa.' ' Frithoilfet c(h)ena,' bhar Cuilenn. Agus ro fersad comrac dicra dur-croidech. Ro gab cach dib ag tuarcain a sceith ar a ceile, go clos go nellaib nime brisc-bruan a m-bocóidedh ${ }^{3}$ 'g a m-brisiud do

a Y.B.L. adds agus gus an deg bhaili. b canas tanic nocha conair bai a thosca.

c Y.B.L. adds do muindtir Medba agus Oilella. d Y.B.L. adds caith-milidh.

e A doirrsiri duna.

$f$ Laech.

$\mathrm{g}$ istaig.

h Dam ni.

i-i Y.B.L. omits.

1 I take aen (aon), 'one' here to mean not 'one man,' but a 'man of renown,' a not uncommon idiom.

2 Cf. vol. i. p. 14. 
Then also Cuilenn, a battle-warrior of Meave and Oilill's people, fared forward to challenge Flann the Tall son of Fidach to fight and combat. He proceeded to Flann's castle and the people were startled at his array, his appearance, and exceeding uncouthness. The doorkeeper asked tidings from him,-whence he came, and the purpose of his visit. He said that he came to challenge Flann the Tall son of Fidach to a duel. 'And you go, doorkeeper,' said he, ' and tell Flann that there is a man of renown here inviting him to combat.' 'What is your name?' asked the doorkeeper. 'Cuilenn is my name,' replied he, 'and I am the man destined to slay Flann the Tall. It is because of this that I have come to challenge him to battle and combat.' And they said the lay :-

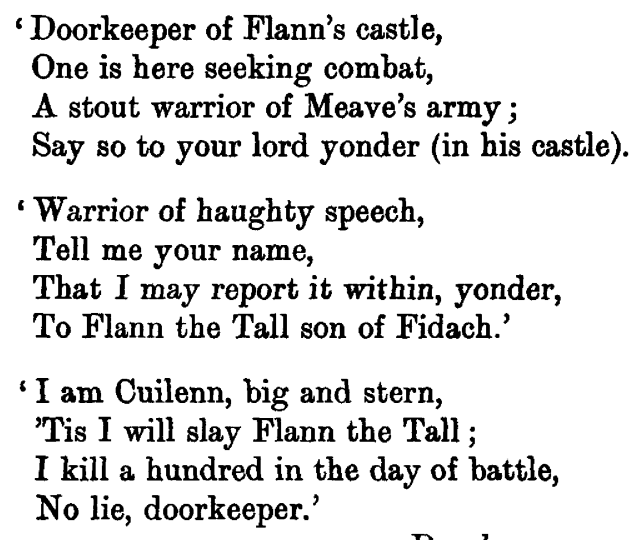

\section{Doorkeeper.}

Flann the Tall thereupon went forth to meet Cuilenn and said to him: 'Cuilenn, if you possess sufficient strength and valour bide a fight with me.' 'I shall certainly do so,' replied Cuilenn. The two fought fiercely, sternly. Each of them struck at the other with his shield, and the crashing sound of the shield bosses as they were broken by the stout

3 bocoid is strictly a spot, a stud or boss of a shield, frequently as here 'a shield.' In Gaelic tale the adj. bucaideach occurs, - a sgiath bhucaideach, bhacaideach, bharrachaol air a laimh chli (West Highland Tales, ii. 459). Bucaideach is evidently from bocoid, while bacaideach is only a variant with change of vowel, 'his embossed (embossed) tapering shield on his left hand.' 
bailc-beimennuib na prím-curadh. Ro tógaib Flann Fada mac Fidaigh an laim n-duaibsich n-denmaich deis, agus do rad béim do'n loirg-fersaid íaruaidi ro bui 'n a laim ar amas cinn Cuilinn cruad-gairb. Do bert Cuilenn toirnedh agus trén-claenad ar a cenn, agus togbáis an scíath go h-urard ar ${ }^{2}$ a formna, go tarla an loirg-fersad lethan lan-mór ${ }^{\mathbf{b}}$ sin a cobraid a sceith agus a mullach na maéili ${ }^{1}$ do Cuilenn, gur scoilt an sgíath con a sceimhlibh, agus co n-derna cilar ${ }^{2}$ combrúighte ${ }^{c}$ d' a cend, co n-ar fágaib urrdail airni dia incinn a n-én inadh, co n-dorchair Cuillenn do'n cruadh-béim sin. Agus tuc beim cloidme dó as a h-aithli, go tobhacht a cend d' á colainn.

Is ann sin ro comairlicestar milidh mor calma, agus airsid imgonda, agus tuaircne ${ }^{d}$ trén catha d' uaislib Erenn, i. Uaithne Uchd-sholas mac Conaill Cernaig dul d' íarraidh echta agus aithesa ar an Gamanraid. Agus ${ }^{\mathrm{e}}$ as edh ro imráid aige dol ${ }^{\mathrm{e}}$ d' innrud agus d' arcain dunaidh agus deg longpuirt ${ }^{f}$ Fraich Column 72. mic Fhidhaigh. Agus ba fiadhnaise d'Oilill agus do Meidb an ní sin. Agus rainic-sium reime d'indsuige ${ }^{g}$ criche agus caimh-ferainn cloinde fraech linmaire ${ }^{3}$ Fidaigh. Agus ro gab crech mor, agus do rinne échta imda ortha. Agus rucatar cáoca macaem do macaemhaib cloindi Fidaigh fair, agus do gab-sum 'g a fobairt go forgruamdha foisdinech. Agus an tan ro bo tressi ${ }^{h}$ dó 'g a marbadh agus 'g a mudhaghad, ${ }^{i}$ as ann rucastar an féinnid fortamail forlann-cruaidh ${ }^{\mathbf{j}}$ fair .i. Fraech mac Fidaigh. And ro aigill iad ar sin, agus ro fiarfaig ${ }^{k}$ ar torrachtain do ${ }^{k}$ cia do bui ann. 'Uaithni Uchtsolus mac Conuill Cernaig,' bhar eisium. 'Mac carad damsa sin,' bhár Fraec(h), 'agus do ronsum cadach agus caradrad ${ }^{4}$ fecht $\mathrm{n}$-aill. Agus tuca-sa do $\mathrm{m}$ ' breithir nach gonfainn Conall na nech dia cloinn go brath, ${ }^{1}$ agus tuc sesium mar an cétna rimsa. Agus o tarla mar tarla mar sin sinn, fagaib-si

a os.

c cilur agus combrudh.

e-e Y.B.L. omits.

L. tressi.

j Y.B.L. adds foistinech. b Y.B.L. adds laech-thuaircthi.

d Y.B.L. (333), tuairgnidh.

s Y.B.L. adds dunaidh agus baili.

i ig malart-mughadh na macraide.

k-k Y.B.L. omits. 1 caidhche.

' maoil, 'temple,' from maol, 'blunt,' 'bald.' Cf. Theid a' chluas thoirt o'n mhaoil, Cuairtear nan Gleann, ii. 119. 
blows of these foremost champions was heard to the clouds of heaven. Flann the Tall son of Fidach raised his dangerous active right hand and aimed a blow at the head of the rough champion Cuilenn with the iron mace which he had in his hand. Cuilenn bent and turned aside his head and raised his shield high above his shoulders. The large and broad mace came down on the centre of Cuilenn's shield and on the top of his skull. The blow cleft the shield with its trappings, and crushed Cuilenn's head into fragments so small that not a bit of his brain of the size of a sloe could be found together. Cuilenn fell by that terrible blow. Thereafter (Flann) by a stroke of his sword cut off his head.

At the same time a great brave warrior and a wounddealing veteran and a mighty commander among the nobles of Ireland, Uaithne Bright-breast son of Conall Cernach, resolved to seek fame and renown among the Gamhanraidh. And he purposed to go and attack and plunder the castle and good stead of Fraoch son of Fidach. Oilill and Meave were made aware of this resolve (of Uaithne). He fared forth to the territory and kindly land of the numerous and fiery clan Fidach. He seized great spoils, and committed many deeds of violence among them. Fifty of the youths of the clan Fidach fell in with him, and he attacked them savagely, relentlessly. While he was at his hardest slaying and destroying them, Fraoch son of Fidach the stout sternlyavenging champion came upon him. He addressed them and at once inquired who they were. "Uaithne Bright-breast son of Conall Cernach,' said he. 'A son of a friend of mine,' replied Fraoch. 'We two at one time made alliance and friendship. I passed my word that I would never attack Conall or any of his family, and he did likewise to me. And seeing things have happened thus, do you leave my herds and

2 I have not met cilar elsewhere. But Dineen has ciolrach, a collective noun, 'shreds,' 'fragments,' evidently formed upon this cilar. The context leaves no doubt as to the meaning.

3 A rather remarkable phrase. Strictly construed fraech qualifies linmaire. Cf. infra fraech fledi firmoire.

4 cadach and caradradh are not now in use in S.G. 
na h-elmha agus na h-innili agumsa, agus na marb an macrad ni bus ${ }^{2}$ mó. Agus do ráid an laid and :-

\author{
'Trec, a Uaithne, an imairec, \\ Agus an re comairli ; \\ Imda na laoich ar lín n-gal, \\ Is na ben re ro gairbhe. \\ ' Sad mac coidi b is combalta, \\ Adfiadhut fir nar tubadh; \\ Ni imeor ort mo cles n-áidh, ${ }^{c}$ \\ Ar baigh re h-ógaib Ulad. \\ 'A mic Conaill coscaraidh, \\ Fagaib m'elbha is m' éide ; \\ Rugsad ort ar sloig ma sech, \\ Fuil sunn nech da n-ab treicthe.'
}

Trec.

Et ni derna Uaithni ar (Fh)ráech ina ar a cinedh an comairli sin, no go n-dechaid fo'n macraid, agus gor cuir ár adbal mor orrta. Agus do gab Fraech a ris 'g á comhairlechadh agus 'g á acallaim. 'Scuir do gnim catha do m' muinntir,' ar se, 'oir ticfaid $m$ ' ferc-sa friut, agus ferc na fine ferrsidhe ${ }^{d}$ fir-beodha-sa do craidhe-si im á crechaib, agus do mudaighis 'm á macraid. Agus treic an cennairc ar a fuile, agus maithfidher dit a n-dernas a m' eniuch-sa agus a n-enech clainni Fidaigh.' Do frecair Uaithni é, agus as edh adubairt :

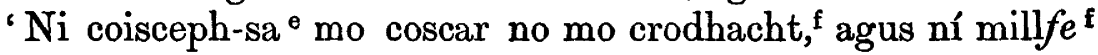
mo baigh no mo breithir re h-Oilill agus re Meidb agus re ceitri h-ollchuigedaib Erenn.' Ro ling ${ }^{\mathrm{g}}$ fo'n macraid agus do marb íad. Do lonnuiged an milidh mor calma ${ }^{\mathrm{h}}$ Fraech fris as a h-aithli, agus ro fer gliadh n-gairb ris con n-orcair Uaithni column 73. do'n n-imaireg.

\footnotetext{
${ }^{a}$ is. b coigni. ${ }^{c}$ n-air.

e caisgium-sa. f.f Y.B.L. omits. B scend.

$n$ in t-ard-mhilidh f chonta .i. Fraech.
} 
cattle unmolested, and cease slaying the youths.' And he said the lay :-

\author{
'Leave off the conflict, Uaithne, \\ And abide by prudent counsel; \\ Many the heroes of great valour, \\ Do not practise excessive cruelty. \\ 'Son of a friend and foster brother, \\ I declare a truth not to be gainsaid, \\ I shall not inflict my slaughter-feat upon you, \\ From my regard for the warriors of Ulster. \\ 'Son of victorious Conall, \\ Leave my herds and property, \\ Our hosts have in turn overtaken you, \\ Here is one who will not desert you.'
}

But Uaithne would have none of that counsel at Fraoch's entreaty or that of his clan. He fell upon the youths and slew a very great number of them. Fraoch again addressed and advised him. 'Cease slaying my people,' said he ; 'otherwise you will incur my wrath and that of this angry and spirited clan, whose cattle you have harried and whose youths you have slain. And leave off this strife in which you are engaged, and I shall forgive what you have done against my honour and that of the clan Fidach.' Uaithne answered and thus spoke: 'I shall not restrain my triumph nor my valour, nor shall I go back on my promise and vow to Oilill and Meave and the four great provinces of Ireland.' He sprang upon the youths and slew them. The great brave warrior Fraoch was furious at this, and he made a fierce attack on Uaithne who fell in that encounter.

(To be continued.) 